\title{
Pertumbuhan dan Hasil Dua Varietas Jagung Manis terhadap Pemberian Pupuk Hayati pada Lahan Rawa Lebak
}

\section{(Growth and Yield Two Sweet Corn Varieties to Biofertilizer Giving on Lebak Wetlands)}

\author{
Achmadi $^{1}$, Mahdiannoor $^{2)}$ \& Nurul Istiqomah ${ }^{3)}$ \\ Program Studi Agroteknologi, Sekolah Tinggi Ilmu Pertanian Amuntai \\ 1)ahmadimx59@gmail.com \\ 2) mahdi_186@yahoo.com \\ ${ }^{3)}$ qoqom_81@yahoo.co.id
}

\begin{abstract}
ABSTRAK
Lahan rawa lebak merupakan lahan yang banyak mempunyai faktor pembatas untuk pengembangan budidaya tanaman pangan khususnya jagung. Faktor pembatas tersebut seperti kelebihan air, kesuburan tanah yang bervariatif dan kandungan unsur-unsur beracun. Upaya yang dapat dilakukan untuk meningkatkan produksi jagung yaitu dengan menggunakan varietas yang tepat dan pemberian pupuk, terutama menggunakan pupuk hayati. Penelitian ini bertujuan untuk mengetahui (i) pengaruh dua varietas jagung manis pada beberapa dosis pupuk hayati, (ii) pengaruh varietas, (iii) pengaruh dosis pupuk hayati, (iv) interaksi varietas dengan pupuk hayati, (v) varietas terbaik dan (vi) dosis pupuk hayati terbaik terhadap pertumbuhan dan hasil dua varietas jagung manis. Penelitian dilaksanakan di Desa Pasar Senin Kecamatan Amuntai Tengah Kabupaten Hulu Sungai Utara dari bulan April - Juli 2017. Menggunakan Rancangan Acak Kelompok (RAK) Faktorial 2 faktor. Faktor pertama varietas jagung manis, yaitu $v_{l}=$ Bonanza $F_{1}$ dan $v_{2}=$ Valentino $F_{1}$. Faktor kedua dosis pupuk hayati yaitu: $h_{0}=0 \mathrm{~kg} . h a^{-1}, h_{1}=50 \mathrm{~kg} . h a^{-1}$ $h_{2}=100 \mathrm{~kg} \cdot \mathrm{ha}^{-1}$ dan $h_{3}=150 \mathrm{~kg} \cdot \mathrm{ha}^{-1}$. Hasil penelitian menunjukan tidak ada interaksi varietas dengan pupuk terhadap semua variabel pengamatan, varietas berpengaruh terhadap tinggi tanaman, jumlah daun, diameter batang, berat tongkol dengan kelobot dan tanpa kelobot, panjang tongkol dengan kelobot dan tanpa kelobot serta diameter tongkol dengan kelobot dan tanpa kelobot dengan perlakuan terbaik adalah $v_{1}$, sedangkan pupuk hayati berpengaruh terhadap berat tongkol dengan kelobot, panjang tongkol dengan kelobot dan tanpa kelobot serta diameter tongkol dengan kelobot dan tanpa kelobot dengan perlakuan terbaik adalah $h_{2}$.
\end{abstract}

Kata kunci : Varietas, jagung manis, pupuk hayati, pengaruh.

\begin{abstract}
Lebak wetland is land that has many limiting factors for the development of food crop cultivation, especially maize. These limiting factors include excess water, varied soil fertility and toxic elements. Efforts that can be made to increase corn production are by using the right varieties and providing fertilizers, especially using biological fertilizers. This study aims to determine (i) the effect of two sweet corn varieties on several doses of biological fertilizers, (ii) the influence of varieties, (iii) the effect of doses of biological fertilizers, (iv) the interaction of varieties with biological fertilizers, (v) the best varieties and (vi) the best dosage of biofertilizer on the growth and yield of two varieties of sweet corn. The study was conducted in Pasar Senin Village, Amuntai Tengah District, Hulu Sungai Utara Regency from April to July 2017. Using a Randomized Block Design (RBD) Factorial 2 factors. The first factor is sweet corn varieties, namely $v_{1}$ $=$ Bonanza $F_{1}$ and $v_{2}=$ Valentino $F_{1}$. The second factor of the dosage of biological fertilizer is: $h_{0}=0$ $\mathrm{kg} . \mathrm{ha}^{-1}, h_{1}=50 \mathrm{~kg} \cdot \mathrm{ha}^{-1}, h_{2}=100 \mathrm{~kg} \cdot \mathrm{ha}^{-1}$ and $h_{3}=150 \mathrm{~kg} \cdot \mathrm{ha}^{-1}$. The results showed no interaction of varieties with fertilizers on all observation variables, varieties had an effect on plant height, number of leaves, stem diameter, ear weight with straws and without weight, ear length with straws and without cornhusk and diameter with strawberries and without nuts with the best treatment is $v_{1}$, while biofertilizer influences the weight of the cob with the weight, the length of the cob with the straw and without the weight and diameter of the cob with the kelobot and without the kelob with the best treatment is $h_{2}$.
\end{abstract}

Keywords: Varieties, sweet corn, biological fertilizer, influence.

Umumnya tanaman jagung manis telah dibudidayakan dengan perawatan yang 
intensif. Berdasarkan data dari Badan Pusat Statistik Daerah Kabupaten Hulu Sungai Utara tahun 2013 luas panen tanaman jagung 127 ha dan hasil produksi jagung 368 ton. Pada tahun 2014 luas panen tanaman jagung 92 ha dan hasil produksi jagung 287 ton dan pada tahun 2015 luas panen tanaman jagung 145 ha dan hasil produksi jagung 457 ton (BPS HSU, 2015).

Salah satu upaya untuk meningkatkan produktivitas jagung adalah menggunakan varietas unggul yang berdaya hasil tinggi dan adaptif dengan lingkungan setempat. Pengembangan varietas unggul baik dari jenis hibrida maupun bersari bebas, telah berkontribusi nyata terhadap peningkatan produktivitas dan produksi. Peran varietas unggul sangat strategis karena terkait dengan beberapa hal yakni: (a) dapat meningkatkan hasil per satuan luas tanam, (b) ketahanan terhadap hama dan penyakit tertentu, (c) daya adaptasi atau kesesuaian pada wilayah atau ekosistem spesifik, dan (d) merupakan komponen teknologi yang relatif mudah/cepat diadopsi petani (Erawati dan Awaludin Hipni, 2009).

Tanah rawa lebak merupakan tanah yang terdapat pada lahan basah. Dalam kondisi alami, tanah rawa lebak merupakan tanah yang selalu jenuh air atau tergenang sepanjang tahun atau dalam waktu yang lama, beberapa bulan dalam setahun (Subagyo, 2006). Purwanto (2006) menambahkan kendala lain adalah tingkat kesuburan tanah yang bervariasi, tingginya kemasaman tanah serta adanya zat beracun $\mathrm{Al}$ dan Fe. Tingkat kemasaman $(\mathrm{pH})$ dilahan rawa lebak umumnya dipengaruhi oleh lingkungan setempat, bahan organik dan perbedaan tingkat oksidasi. Pada musim kemarau tanah lebih teroksidasi dan lebih salin sehingga kemasaman meningkat $(\mathrm{pH}$ lebih rendah). Sebaliknya pada musim hujan, kemasaman dapat menurun selain terjadi pengenceran juga terjadi proses reduksi. Namun, apabila terjadi tumpat air berkepanjangan dan lama, maka terjadi perombakan secara anaerob terhadap bahan organik yang memunculkan penimbunan asam-asam organik sehingga terjadi pemasaman (acidification) (Noor, 2007).
Mikroba di dalam tanah dapat bekerja maksimal pada kondisi lingkungan dengan kelembaban rendah dan memiliki tata udara yang baik (Sutanto, 2006 dalam Mahdiannoor, 2014). Sehingga dengan adanya pengolahan tanah yang dilakukan sebelum penanaman dan penyiraman dengan tujuan menjaga kelembaban tanah, menyebabkan bakteri Azotobacter sp. yang berasal dari pupuk hayati dapat bekerja maksimal dalam meningkat nitrogen di udara.

Pupuk hayati berisi mikroorganisme penghancur bahan-bahan organik (dekomposer) sehingga tanah menjadi gembur, mampu menahan air lebih banyak dan akar tanaman dapat berkembang dengan maksimal. Merangsang perkembangan akar tanaman karena dapat menghasilkan zat pengatur tumbuh (Laiya et. al., 2013).

Menurut Setiawan (1993) dalam Nurhayati (2006), pertumbuhan produksi dan mutu hasil jagung manis dipengaruhi oleh dua faktor yaitu faktor genetik dan faktor lingkungan seperti kesuburan tanah. Upaya yang dapat dilakukan untuk meningkatkan kesuburan tanah adalah dengan pemberian pupuk baik pupuk organik maupun pupuk anorganik.

Pupuk hayati atau sering disebutkan biofertilizer yaitu pupuk yang dibuat dari mikroba yang mempunyai kemampuan untuk menyediakan unsur hara bagi tanaman, misalnya kebutuhan nitrogen, fosfat, $\mathrm{Mg}, \mathrm{Zn}$ dan $\mathrm{Cu}$. Penerapan pupuk hayati Rhizobium pada budidaya tanaman kacang-kacangan dapat meningkatkan hasil rata-rata $13-50 \%$. Pada jenis-jenis mikroba yang non-simbiotik umumnya mengeluarkan senyawa aktif tertentu (enzim) yang mampu meluruhkan unsur yang terikat dengan tanah sehingga dapat diserap oleh tanaman (Suwahyono, 2011).

Azotobacter chroococcum adalah jenis bakteri yang mampu meluruhkan atau menyediakan fosfat dan nitrogen bagi tanaman di dalam tanah. Pada tanaman sorgum menunjukkan bahwa pemberian Azotobacter dapat meningkatkan hasil sebesar 9,3-38\%, pada tanaman jagung sebesar 36,5-71,7\% dan pada tanaman kapas 
meningkatkan hasil sebesar 6,7-20,6\% (Suwahyono, 2011).

Penambahan

pupuk

hayati/biofertilizer dapat memperbaiki sifat fisik, kimia dan biologi tanaman sehingga peningkatan populasi bakteri tanah dan pertumbuhan tanaman kina. Pengoptimalan tanah sebagai suatu kekuatan biologis memerlukan beberapa pemahaman tentang kondisi yang sesuai untuk berbagai organisme tanah serta berbagai mikroorganisme menguntungkan dalam tanah, seperti bakteri penambat nitrogen dan bakteri pelarut fosfat (Antralina et. al., 2015). Menurut Laiya et. al., (2013), perlakuan pupuk hayati terbaik yang berpengaruh pada pertumbuhan dan produksi jagung hibrida terdapat pada dosis pupuk hayati $50 \mathrm{~kg} . \mathrm{ha}-1$ dan pupuk hayati diberikan pada saat tanaman berumur 14 dan 35 HST.

Penelitian ini bertujuan untuk mengetahui (i) pengaruh dua varietas jagung manis pada beberapa dosis pupuk hayati, (ii) pengaruh varietas, (iii) pengaruh dosis pupuk hayati, (iv) interaksi varietas dengan pupuk hayati, (v) varietas terbaik dan (vi) dosis pupuk hayati terbaik terhadap pertumbuhan dan hasil dua varietas jagung manis.

\section{METODE PENELITIAN}

Penelitian ini dilaksanakan di Desa Pasar Senin Kecamatan Amuntai Tengah Kabupaten Hulu Sungai Utara Provinsi Kalimantan Selatan pada bulan Maret - Mei 2017. Bahan yang digunakan antara lain benih jagung manis Varietas Bonanza $F_{1}$ dan Valentino $F_{1}$, lahan rawa lebak, pupuk hayati petro biofertil dan air. Ala tantara lain cangkul, parang, meteran, tugal, handsprayer, gembor, timbangan, jangka sorong, alat dokumentasi dan alat tulis.

Penelitian ini merupakan percobaan yang dilaksanakan di lapangan dengan menggunakan Rancangan Acak Kelompok (RAK) Faktorial yang terdiri dari 2 faktor. Pengelompokan berdasarkan topografi lahan. Faktor yang diuji adalah dua varietas jagung manis dan dosis pupuk hayati petro biofertil. Faktor pertama adalah varietas jagung manis (V) yaitu : $\mathrm{v}_{1}=$ Varietas Bonanza $\mathrm{F}_{1}$ dan $\mathrm{v}_{2}=$
Varietas Valentino $F_{1}$. Faktor kedua adalah dosis pupuk hayati $(\mathrm{H})$ terdiri dari 4 taraf, yaitu : $\mathrm{h}_{0}=0 \mathrm{~kg} \cdot \mathrm{ha}^{-1}$ setara dengan 0 g.petak ${ }^{1}, \mathrm{~h}_{1}=50 \mathrm{~kg} \cdot \mathrm{ha}^{-1}$ setara dengan 15,625 g.petak ${ }^{-1}, \mathrm{~h}_{2}=100 \mathrm{~kg} \cdot \mathrm{ha}^{-1}$ setara dengan 31,25 g.petak ${ }^{-1}$ dan $\mathrm{h}_{3}=150 \mathrm{~kg} \cdot \mathrm{ha}^{-1}$ setara dengan 46,875 g.petak ${ }^{-1}$. Seluruh percobaan sebanyak 8 kombinasi perlakuan dan diulang sebanyak 3 kali, sehingga didapatkan 24 satuan percobaan. Dimana setiap percobaan terdiri dari 4 tanaman sampel yang diamati, sehingga jumlah tanaman sampel semuanya adalah 96 tanaman.

Pelaksanaan penelitian terdiri dari persiapan, pembersihan lahan, pengolahan lahan, pemupukan, penanaman, penyulaman, penjarangan, pemeliharaan tanaman dan panen. Pengamatan yang dilakukan dalam penelitian ini adalah peubah tinggi tanaman, jumlah daun, diameter batang, berat tongkol dengan dan tanpa kelobot, panjang tongkol dengan dan tanpa kelobot, diameter tongkol dengan dan tanpa kelobot.

Analisis data yang digunakan antara lain data tersebut dilakukan uji kehomogenannya dengan uji Bartllet, bila sudah homogen dari setiap perlakuan, kemudian dilanjutkan dangan analisis ragam menggunakan uji-F pada taraf nyata $5 \%$ dan $1 \%$. Apabila uji-F menunjukkan pengaruh nyata atau sangat nyata maka analisis dilanjutkan dengan Uji Jarak Berganda Duncan (DMRT) pada taraf nyata 5\% (Langai, 2003).

\section{HASIL DAN PEMBAHASAN}

\section{Hasil}

\section{Tinggi Tanaman}

Berdasarkan hasil analisis ragam diketahui bahwa tidak ada interaksi antara varietas dengan pupuk hayati, sedangkan perlakuan tunggal varietas berpengaruh nyata dan perlakuan tunggal pupuk hayati tidak berpengaruh terhadap tinggi tanaman jagung manis. Hasil uji rata-rata tinggi tanaman jagung manis pada perlakuan varietas dapat dilihat pada Tabel 1 . 
Tabel 1. Hasil uji rata-rata tinggi tanaman jagung manis umur 14, 21 dan 28 HST pada perlakuan varietas

\begin{tabular}{cccc}
\hline \multirow{2}{*}{ Perlakuan } & \multicolumn{3}{c}{ Rata-Rata Tinggi Tanaman $(\mathrm{cm})$} \\
\cline { 2 - 4 } & $14 \mathrm{HST}$ & $21 \mathrm{HST}$ & $28 \mathrm{HST}$ \\
\hline $\mathrm{v}_{1}$ & 15,77 & 24,21 & $38,92^{\mathrm{b}}$ \\
$\mathrm{v}_{2}$ & 15,79 & 23,73 & $35,50^{\mathrm{a}}$ \\
\hline
\end{tabular}

Keterangan : Nilai rata-rata yang diikuti oleh huruf yang sama pada kolom yang sama menunjukan perlakuan tersebut tidak berbeda berdasarkan DMRT pada taraf $5 \%$

Dari Tabel 3 terlihat bahwa pada umur 14 dan 21 perlakuan tidak berpengaruh. Pada umur 28 HST perlakuan $\mathrm{v}_{1}$ menunjukan tinggi tanaman lebih tinggi yaitu $38,92 \mathrm{~cm}$ yang berbeda dengan perlakuan $\mathrm{v}_{2}$ yaitu $35,50 \mathrm{~cm}$. Perlakuan terbaik didapatkan pada $\mathrm{v}_{1}$.

\section{Jumlah Daun}

Berdasarkan hasil analisis ragam diketahui tidak ada interaksi antara varietas dengan pupuk hayati dan perlakuan tunggal varietas serta dosis pupuk hayati juga tidak berpengaruh terhadap jumlah daun tanaman jagung manis. Diagram jumlah daun tanaman jagung manis pada perlakuan dua varietas dan berbagai dosis pupuk hayati dapat dilihat pada Gambar 1.

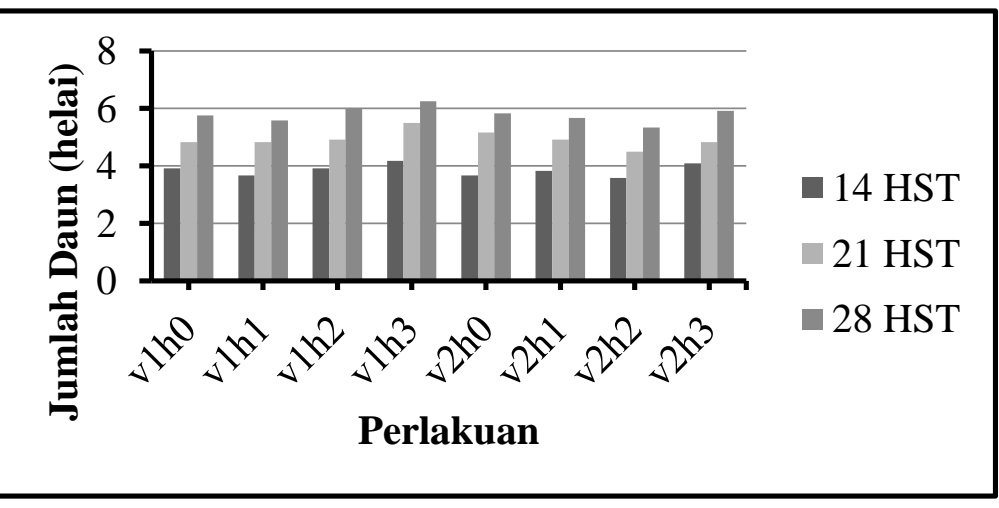

Gambar 2. Diagram Jumlah daun tanaman (helai) pada perlakuan varietas dan pupuk hayati

Dari diagram dapat dilihat bahwa pada umur 28 HST perlakuan Varietas Bonanza $F_{1}$ dan dosis pupuk hayati $150 \mathrm{~kg} \cdot \mathrm{ha}^{-1}\left(\mathrm{v}_{1} \mathrm{~h}_{3}\right)$ menghasilkan rata-rata jumlah daun paling banyak yaitu 6,25 helai.

\section{Diameter Batang}

Berdasarkan hasil analisis ragam diketahui tidak ada interaksi antara varietas dengan pupuk hayati dan perlakuan tunggal pupuk hayati tidak berpengaruh, sedangkan perlakuan tunggal varietas berpengaruh nyata terhadap diameter batang tanaman jagung manis. Hasil uji rata-rata diameter batang tanaman jagung manis pada perlakuan varietas dapat dilihat pada Tabel 2.

Tabel 2. Hasil uji rata-rata diameter batang tanaman jagung manis umur 14, 21 dan 28 HST pada perlakuan varietas

\begin{tabular}{cccc}
\hline \multirow{2}{*}{ Perlakuan } & \multicolumn{3}{c}{ Rata-Rata Diameter Batang $(\mathrm{cm})$} \\
\cline { 2 - 4 } & $14 \mathrm{HST}$ & $21 \mathrm{HST}$ & $28 \mathrm{HST}$ \\
\hline $\mathrm{v}_{1}$ & $0,44^{\mathrm{b}}$ & 0,64 & 0,92 \\
$\mathrm{v}_{2}$ & $0,37^{\mathrm{a}}$ & 0,66 & 0,96 \\
\hline
\end{tabular}

Keterangan : Nilai rata-rata yang diikuti oleh huruf yang sama pada kolom yang sama menunjukan perlakuan tersebut tidak berbeda berdasarkan DMRT pada taraf 5\% 
Dari Tabel 2 terlihat bahwa pada umur 14 HST perlakuan $\mathrm{v}_{1}$ menunjukan diameter batang paling besar yaitu $0,44 \mathrm{~cm}$ berbeda dengan perlakuan $\mathrm{v}_{2}$. Pada umur $21 \mathrm{HST}$ perlakuan $\mathrm{v}_{2}$ menunjukan tinggi tanaman paling tinggi yaitu $0,66 \mathrm{~cm}$ yang tidak berbeda dengan perlakuan $\mathrm{v}_{1}$. Pada umur 28 HST perlakuan $v_{2}$ menunjukan tinggi tanaman paling tinggi yaitu $0,96 \mathrm{~cm}$ yang tidak berbeda dengan perlakuan $\mathrm{v}_{1}$.

\section{Berat Tongkol dengan Kelobot}

Berdasarkan hasil analisis ragam diketahui tidak ada interaksi antara varietas dengan pupuk hayati, sedangkan perlakuan tunggal varietas berpengaruh sangat nyata dan perlakuan tunggal pupuk hayati berpengaruh nyata terhadap berat tongkol dengan kelobot. Hasil uji rata-rata berat tongkol dengan kelobot jagung manis pada perlakuan varietas dan pupuk hayati dapat dilihat pada Tabel 3.

Tabel 3. Hasil uji rata-rata berat tongkol dengan kelobot jagung manis pada perlakuan varietas dan pupuk hayati

\begin{tabular}{|c|c|}
\hline Perlakuan & Rata-rata berat tongkol dengan kelobot (g) \\
\hline \multicolumn{2}{|l|}{ Varietas $(\mathrm{V})$} \\
\hline $\mathrm{V}_{1}$ & $200,42^{\mathrm{b}}$ \\
\hline $\mathrm{v}_{2}$ & $190,00^{\mathrm{a}}$ \\
\hline \multicolumn{2}{|l|}{ Dosis pupuk hayati $(\mathrm{H})$} \\
\hline $\mathrm{h}_{0}$ & $189,17^{\mathrm{a}}$ \\
\hline $\mathrm{h}_{1}$ & $189,17^{\mathrm{a}}$ \\
\hline $\mathrm{h}_{2}$ & $200,83^{\mathrm{ab}}$ \\
\hline $\mathrm{h}_{3}$ & $201,67^{b}$ \\
\hline
\end{tabular}

Keterangan : Nilai rata-rata yang diikuti oleh huruf yang sama pada kolom yang sama menunjukan perlakuan tersebut tidak berbeda berdasarkan DMRT pada taraf 5\%.

Dari Tabel 3 terlihat bahwa perlakuan $\mathrm{v}_{1}$ menunjukan berat tongkol dengan kelobot paling berat yaitu 200,42 g yang berbeda dengan perlakuan $v_{2}$. Pada perlakuan $h_{3}$ menunjukan berat tongkol dengan kelobot paling berat yaitu 201,67 g tidak berbeda dengan perlakuan $h_{2}$ dan berbeda dengan perlakuan $\mathrm{h}_{1}$ dan $\mathrm{h}_{0}$.

\section{Berat Tongkol tanpa Kelobot}

Tabel 4. Hasil uji rata-rata berat tongkol tanpa kelobot jagung manis pada perlakuan varietas dan pupuk hayati

\begin{tabular}{|c|c|}
\hline Perlakuan & Rata-rata berat tongkol tanpa kelobot $(\mathrm{g})$ \\
\hline \multicolumn{2}{|l|}{ Varietas (V) } \\
\hline $\mathrm{v}_{1}$ & $159,59^{\mathrm{b}}$ \\
\hline $\mathrm{v}_{2}$ & $149,58^{a}$ \\
\hline \multicolumn{2}{|c|}{ Dosis pupuk hayati $(\mathrm{H})$} \\
\hline $\mathrm{h}_{0}$ & $152,50^{\mathrm{ab}}$ \\
\hline $\mathrm{h}_{1}$ & $147,50^{\mathrm{a}}$ \\
\hline $\mathrm{h}_{2}$ & $158,33^{\mathrm{ab}}$ \\
\hline $\mathrm{h}_{3}$ & $160,00^{\mathrm{b}}$ \\
\hline
\end{tabular}

Keterangan : Nilai rata-rata yang diikuti oleh huruf yang sama pada kolom yang sama menunjukan perlakuan tersebut tidak berbeda berdasarkan DMRT pada taraf 5\%. 
Dari Tabel 4 terlihat bahwa perlakuan $\mathrm{v}_{1}$ menunjukan berat tongkol tanpa kelobot paling berat yaitu $159,59 \mathrm{~g}$ yang berbeda dengan perlakuan $\mathrm{v}_{2}$. Pada perlakuan $\mathrm{h}_{3}$ menunjukan berat tongkol tanpa kelobot paling berat yaitu $160,00 \mathrm{~g}$ tidak berbeda dengan perlakuan $\mathrm{h}_{2}$ dan $\mathrm{h}_{0}$, tapi berbeda dengan $\mathrm{h}_{1}$.

\section{Panjang Tongkol dengan Kelobot}

Berdasarkan hasil analisis ragam diketahui tidak ada interaksi antara varietas dengan pupuk hayati, sedangkan perlakuan tunggal varietas berpengaruh sangat nyata dan perlakuan tunggal pupuk hayati berpengaruh nyata terhadap panjang tongkol dengan kelobot. Hasil uji rata-rata panjang tongkol dengan kelobot jagung manis pada perlakuan varietas dan pupuk hayati dapat dilihat pada Tabel 5.

Tabel 5. Hasil uji rata-rata panjang tongkol dengan kelobot jagung manis pada perlakuan varietas dan pupuk hayati

\begin{tabular}{cc}
\hline Perlakuan & Rata-rata panjang tongkol dengan kelobot $(\mathrm{cm})$ \\
\hline Varietas $(\mathrm{V})$ & \\
$\mathrm{v}_{1}$ & $21,83^{\mathrm{b}}$ \\
$\mathrm{v}_{2}$ & $20,58^{\mathrm{a}}$ \\
\hline Dosis pupuk hayati $(\mathrm{H})$ & \\
\hline $\mathrm{h}_{0}$ & $20,17^{\mathrm{a}}$ \\
$\mathrm{h}_{1}$ & $21,17^{\mathrm{ab}}$ \\
$\mathrm{h}_{2}$ & $21,33^{\mathrm{ab}}$ \\
$\mathrm{h}_{3}$ & $22,17^{\mathrm{b}}$ \\
\hline
\end{tabular}

Keterangan : Nilai rata-rata yang diikuti oleh huruf yang sama pada kolom yang sama menunjukan perlakuan tersebut tidak berbeda berdasarkan DMRT pada taraf 5\%

Dari Tabel 5 terlihat bahwa perlakuan $\mathrm{v}_{1}$ menunjukan panjang tongkol dengan kelobot paling panjang yaitu $21,83 \mathrm{~cm}$ yang berbeda dengan perlakuan $\mathrm{v}_{2}$, sedangkan pada perlakuan $\mathrm{h}_{3}$ menunjukan panjang tongkol dengan kelobot paling panjang yaitu $22,17 \mathrm{~cm}$ yang tidak berbeda dengan perlakuan $h_{1}$ dan $h_{2}$ dan berbeda dengan perlakuan $\mathrm{h}_{0}$.

\section{Panjang Tongkol tanpa Kelobot}

Tabel 6. Hasil uji rata-rata panjang tongkol tanpa kelobot jagung manis pada perlakuan varietas dan pupuk hayati

\begin{tabular}{|c|c|}
\hline Perlakuan & Rata-rata panjang tongkol tanpa kelobot $(\mathrm{cm})$ \\
\hline \multicolumn{2}{|l|}{ Varietas $(\mathrm{V})$} \\
\hline $\mathrm{v}_{1}$ & $18,25^{\mathrm{b}}$ \\
\hline $\mathrm{v}_{2}$ & $17,08^{\mathrm{a}}$ \\
\hline \multicolumn{2}{|c|}{ Dosis pupuk hayati $(\mathrm{H})$} \\
\hline $\mathrm{h}_{0}$ & $16,00^{\mathrm{a}}$ \\
\hline $\mathrm{h}_{1}$ & $17,67^{\mathrm{ab}}$ \\
\hline $\mathrm{h}_{2}$ & $18,17^{\mathrm{ab}}$ \\
\hline $\mathrm{h}_{3}$ & $18,83^{\mathrm{b}}$ \\
\hline
\end{tabular}

Keterangan : Nilai rata-rata yang diikuti oleh huruf yang sama pada kolom yang sama menunjukan perlakuan tersebut tidak berbeda berdasarkan DMRT pada taraf 5\%

\begin{abstract}
Berdasarkan hasil analisis ragam diketahui tidak terdapat interaksi antara varietas dengan pupuk hayati, sedangkan perlakuan tunggal varietas berpengaruh nyata dan perlakuan tunggal pupuk hayati berpengaruh sangat nyata terhadap panjang tongkol tanpa kelobot. Hasil uji rata-rata panjang tongkol tanpa kelobot jagung manis pada perlakuan varietas dan pupuk hayati dapat dilihat pada Tabel 6 .
\end{abstract}


Dari Tabel 6 terlihat bahwa perlakuan $\mathrm{V}_{1}$ menunjukan panjang tongkol tanpa kelobot jagung manis paling panjang yaitu $18,25 \mathrm{~cm}$ yang berbeda dengan perlakuan $\mathrm{v}_{2}$, sedangkan pada perlakuan $\mathrm{h}_{3}$ menunjukan panjang tongkol tanpa kelobot jagung manis paling panjang yaitu $18,83 \mathrm{~cm}$ yang tidak berbeda dengan perlakuan $h_{2}$ dan $h_{1}$, berbeda dengan perlakuan $\mathrm{h}_{0}$.

\section{Diameter Tongkol dengan Kelobot}

Berdasarkan hasil analisis ragam diketahui tidak terdapat interaksi antara varietas dengan pupuk hayati, sedangkan perlakuan tunggal varietas berpengaruh sangat nyata dan perlakuan tunggal pupuk hayati berpengaruh nyata terhadap diameter tongkol dengan kelobot. Hasil uji rata-rata diameter tongkol dengan kelobot jagung manis pada perlakuan varietas dan pupuk hayati dapat dilihat pada Tabel 7.

Tabel 7. Hasil uji rata-rata diameter tongkol dengan kelobot jagung manis pada perlakuan varietas dan pupuk hayati

\begin{tabular}{cc}
\hline Perlakuan & Rata-rata diameter tongkol dengan kelobot $(\mathrm{cm})$ \\
\hline Varietas $(\mathrm{V})$ & $5,09^{\mathrm{b}}$ \\
$\mathrm{V}_{1}$ & $4,29^{\mathrm{a}}$ \\
$\mathrm{v}_{2}$ & \\
\hline Dosis pupuk hayati $(\mathrm{H})$ & $4,17^{\mathrm{a}}$ \\
\hline $\mathrm{h}_{0}$ & $4,58^{\mathrm{ab}}$ \\
$\mathrm{h}_{1}$ & $4,92^{\mathrm{ab}}$ \\
$\mathrm{h}_{2}$ & $5,09^{\mathrm{b}}$ \\
$\mathrm{h}_{3}$ & \\
\hline
\end{tabular}

Keterangan : Nilai rata-rata yang diikuti oleh huruf yang sama pada kolom yang sama menunjukan perlakuan tersebut tidak berbeda berdasarkan DMRT pada taraf 5\%

Dari Tabel 7 terlihat bahwa perlakuan $\mathrm{v}_{1}$ menunjukan diameter tongkol dengan kelobot jagung manis paling besar yaitu 5,09 $\mathrm{cm}$ yang berbeda dengan perlakuan $\mathrm{v}_{2}$, sedangkan pada perlakuan $\mathrm{h}_{3}$ menunjukan diameter tongkol dengan kelobot jagung manis paling besar yaitu $5,09 \mathrm{~cm}$ yang berbeda dengan perlakuan $\mathrm{h}_{0}$, tidak berbeda dengan $\mathrm{h}_{1}$ dan $\mathrm{h}_{3}$.

\section{Diameter Tongkol tanpa Kelobot}

Berdasarkan hasil analisis ragam diketahui tidak terdapat interaksi antara varietas dengan pupuk hayati, sedangkan perlakuan tunggal varietas berpengaruh sangat nyata dan perlakuan tunggal pupuk hayati berpengaruh nyata terhadap diameter tongkol tanpa kelobot. Hasil uji rata-rata diameter tongkol tanpa kelobot jagung manis pada perlakuan varietas dan pupuk hayati dapat dilihat pada Tabel 8.

Tabel 8. Hasil uji rata-rata diameter tongkol tanpa kelobot jagung manis pada perlakuan varietas dan pupuk hayati

\begin{tabular}{|c|c|}
\hline Perlakuan & Rata-rata diameter tongkol tanpa kelobot $(\mathrm{cm})$ \\
\hline \multicolumn{2}{|l|}{ Varietas $(\mathrm{V})$} \\
\hline 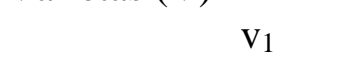 & $4,04^{b}$ \\
\hline $\mathrm{V}_{2}$ & $3,46^{\mathrm{a}}$ \\
\hline \multicolumn{2}{|l|}{ Dosis pupuk hayati $(\mathrm{H})$} \\
\hline $\mathrm{h}_{0}$ & $3,33^{\mathrm{a}}$ \\
\hline $\mathrm{h}_{1}$ & $3,67^{\mathrm{ab}}$ \\
\hline $\mathrm{h}_{2}$ & $3,92^{\mathrm{ab}}$ \\
\hline $\mathrm{h}_{3}$ & $4,08^{b}$ \\
\hline
\end{tabular}


Keterangan : Nilai rata-rata yang diikuti oleh huruf yang sama pada kolom yang sama menunjukan perlakuan tersebut tidak berbeda berdasarkan DMRT pada taraf 5\%

Dari Tabel 8 terlihat bahwa perlakuan $\mathrm{v}_{1}$ menunjukan diameter tongkol tanpa kelobot jagung manis paling besar yaitu 4,04 $\mathrm{cm}$ yang berbeda dengan perlakuan $\mathrm{v}_{2}$, sedangkan pada perlakuan $\mathrm{h}_{3}$ menunjukan diameter tongkol tanpa kelobot jagung manis paling besar yaitu $4,08 \mathrm{~cm}$ yang tidak berbeda dengan perlakuan $h_{1}$ dan $h_{2}$, berbeda dengan perlakuan $\mathrm{h}_{0}$.

\section{Pembahasan}

\section{Interaksi Varietas dengan Pupuk Hayati}

Hasil analisis ragam menunjukan bahwa interaksi varietas dengan pupuk hayati tidak berpengaruh terhadap semua variabel. Hal ini disebabkan oleh tinggi dan rendahnya kemampuan setiap mikroba yang terdapat di dalam pupuk hayati berbeda-beda dalam mensubtitusi unsur hara bagi tanaman dan beradaptasi pada tempat pertumbuhannya, serta kemampuan yang berbeda di setiap varietas dalam bersimbiosis terhadap kandungan mikroba dalam pupuk hayati. Hal ini sejalan dengan Iskandar (2002) dalam Hawayanti et. al., (2015), kemampuan setiap mikroba didalam tanah sangat berbeda beda dalam meyuplai unsur hara, hal ini dapat disebabkan daya adaptasi dan pertumbuhan mikroba tersebut seperti terhadap kemasaman tanah, suhu, kadar air tanah, bahan organik maupun cahaya.

\section{Varietas}

Berdasarkan hasil pengamatan pertumbuhan vegetatif tanaman jagung manis semakin meningkat seiring dengan bertambahnya umur, tetapi pada masingmasing variabel pengamatan, pengaruh yang didapatkan dari perlakuan dua varietas jagung manis juga berbeda. Hasil analisis ragam menunjukan bahwa perlakuan varietas berpengaruh terhadap tinggi tanaman. Hal ini diduga karena tinggi tanaman dipengaruhi oleh faktor genetik dari varietas yang diuji. Sesuai dengan pernyataan Gardner et. al., (1991) dalam Mahdiannoor dan Nurul Istiqomah (2015), bahwa pengaruh varietas terhadap variabel pengamatan disebabkan karena perbedaan faktor genetik yang dimiliki oleh masing-masing varietas jagung dan kemampuan adaptasinya terhadap lingkungan. Leiwakabessi (1998) dalam Dewi dan Jumini (2010), menambahkan bahwa varietas yang mampu beradaptasi lebih cepat dengan lingkungannya cenderung memiliki respons yang lebih baik terhadap pertumbuhan dan hasil dibandingkan dengan varietas yang lambat beradaptasi walaupun secara genotipe memiliki kemampuan tumbuh yang sama.

Pada variabel pengamatan jumlah daun perlakuan varietas tidak berpengaruh. Hal ini diduga karena jumlah daun tidak dipengaruhi oleh varietas. Subekti et. al., (2007) dalam Mahdiannoor dan Nurul Istiqomah (2015), menyatakan bahwa setiap daun terdiri atas helaian daun, ligula, dan pelepah daun yang erat melekat pada batang. Jumlah daun sama dengan jumlah buku batang. Jumlah daun umumya berkisar antara 10-18 helai, rata-rata munculnya daun yang terbuka sempurna adalah 3-4 hari setiap daun.

Pada variabel pengamatan diameter batang perlakuan varietas jagung manis berpengaruh pada umur 14 HST. Sedangkan pada umur 21 HST dan 28 HST tidak dipengaruhi oleh varietas. Sejalan dengan hasil penelitian Abidin et. al., (2017), menunjukkan bahwa pada awal fase vegetatif tidak memberikan pengaruh apapun baik dari perlakuan pupuk petroganik maupun mikoriza. Sedangkan pada fase generatif perlakuan tunggal varietas juga berpengaruh terhadap berat tongkol tanpa kelobot, panjang tongkol dengan kelobot dan panjang tongkol tanpa kelobot dan diameter tongkol tanpa kelobot serta berpengaruh sangat nyata terhadap berat tongkol dengan kelobot dan diameter tongkol dengan kelobot. Hal ini diduga karena tanaman jagung manis cenderung dipengaruhi oleh faktor genetik. Hasil ini sejalan dengan penelitian Ningsih et. al., (2015), bahwa panjang tongkol, diameter batang, berat tongkol pertanaman, berat tongkol perpetak dan berat kering berangkasan di pengaruhi oleh varietas 
jagung manis. Hal senada juga dikemukakan oleh Zainuddin (2005), bahwa panjang tongkol dan diameter tongkol juga dipengaruhi oleh 3 macam varietas jagung manis.

Berdasarkan uji DMRT 5\%, rata-rata perlakuan v1 menunjukkan perlakuan tertinggi yang tidak berbeda dengan rata-rata perlakuan $\mathrm{v}_{2}$, sehingga didapatkan perlakuan terbaik pada perlakuan v1 atau pada Varietas Bonanza $F_{1}$, karena dilihat dari segi ekonomis harga Varietas Bonanza $\mathrm{F}_{1}$ lebih murah dan mudah didapat dipasaran dibandingkan dengan Varietas Valentino $F_{1}$. Dua varietas yang ditanam merupakan jenis jagung manis hibrida. Jagung hibrida merupakan hasil perkawinan antara kedua jenis jagung yang terdiri dari galur murni sehingga terjadi perpaduan sifat unggul (Riani et. al., 2001 dalam Patola dan Sri Hardiatmi (2011), varietas hibrida mempunyai potensi hasil yang tinggi, daya adaptasi luas, pertumbuhan dan hasil tanaman lebih seragam, tahan penyakit bulai dan karat daun. Perbedaan penampilan (fenotipe) dari berbagai varietas hibrida diakibatkan pengaruh genetik dan lingkungan. Gen-gen yang beragam dari masing-masing varietas mempunyai karakter yang beragam pula. Lingkungan memberikan peranan dalam rangka penampakan karakter yang sebenarnya terkandung dalam gen tersebut. Penampilan suatu gen masih labil karena masih dipengaruhi oleh faktor lingkungan sehingga sering didapatkan tanaman sejenis tapi dengan karakter yang berbeda. Setiap hibrida menunjukkan pertumbuhan dan hasil yang beragam sebagai akibat dari pengaruh genetik dan lingkungan, dimana pengaruh genetik merupakan pengaruh keturunan yang dimiliki oleh setiap galur sedangkan pengaruh lingkungan adalah pengaruh yang ditimbulkan oleh habitat dan kondisi lingkungan. Hasil penelitian menunjukkan bahwa Varietas Bonanza $\mathrm{F}_{1}$ memiliki daya adaptasi yang lebih tinggi dibanding Varietas Valentino $F_{1}$.

\section{Pupuk Hayati}

Hasil analisis ragam menunjukan bahwa perlakuan tunggal pupuk hayati tidak berpengaruh terhadap tinggi tanaman, jumlah daun dan diameter batang (fase vegetatif). Hal ini diduga respon akar terhadap penyerapan unsur hara masih dalam jumlah yang sedikit, karena mikroba yang diberikan ke dalam tanah belum mampu berfungsi secara optimal untuk membantu akar dalam penyerapan unsur hara yang diberikan. Sehingga pemberian pupuk hayati belum mampu memenuhi kebutuhan hara bagi tanaman dalam mendukung pertumbuhan tanaman jagung manis.

Menurut Syafruddin (2012) dalam Ningsih et. al., (2015), menyatakan bahwa ketersediaan hara yang cukup dan seimbang akan mempengaruhi proses metabolisme pada jaringan tanaman. Proses metabolisme merupakan pembentukan dan perombakan unsur-unsur hara dan senyawa organik dalam tanaman. Kekurangan unsur hara tertentu dalam tanaman dapat berakibat buruk dan bila terlalu berlebihan dapat merusak pertumbuhan tanaman itu sendiri.

Hasil penelitian menunjukkan bahwa pengaruh pupuk hayati bersifat lambat dan baru terlihat saat memasuki fase generatif. Hal ini sejalan dengan penelitian Husen (2013) bahwa respon tanaman jagung dan tomat terhadap pupuk hayati HEG dan BTC yang tergolong lambat dan baru terlihat pada fase akhir masa pertumbuhan vegetatif diduga terkait dengan rendahnya kepadatan populasi mikroba (104 -107 per g atau ml bahan pembawa), sehingga beberapa karakter fungsional mikroba dalam menambat $\mathrm{N}_{2}$, melarutkan $\mathrm{P}$ atau memacu pertumbuhan tanaman belum bekerja secara optimal.

Pada fase generatif perlakuan pupuk hayati berpengaruh terhadap berat tongkol dengan kelobot, panjang tongkol dengan kelobot dan tanpa kelobot, diameter tongkol dengan kelobot dan tanpa kelobot. Hal ini diduga karena pada setiap perlakuan kondisi unsur hara sudah cukup tersedia bagi tanaman sehingga dapat mendukung pertumbuhan tanaman.

Berdasarkan hasil uji DMRT 5\%, hasil ratarata pada perlakuan $h_{3}$ menunjukkan hasil tertinggi yang tidak berbeda nyata dengan hasil rata-rata pada perlakuan $\mathrm{h}_{2}$, sehingga didapatkan perlakuan terbaik pada perlakuan $\mathrm{h}_{3}$ atau pada dosis $150 \mathrm{~kg} \cdot \mathrm{ha}^{-1}$ setara dengan 46,875 g.petak ${ }^{-1}$. Hal ini diduga jumlah unsur 
hara yang terkandung dalam pupuk hayati berada dalam jumlah yang tepat.

\section{KESIMPULAN}

Berdasarkan hasil penelitian maka dapat diambil kesimpulan sebagai berikut : tidak terdapat interaksi antara varietas dengan dosis pupuk hayati terhadap semua variabel pengamatan, varietas berpengaruh terhadap tinggi tanaman, diameter batang, berat tongkol dengan kelobot dan tanpa kelobot, panjang tongkol dengan kelobot dan tanpa kelobot serta diameter tongkol dengan kelobot dan tanpa kelobot, pupuk hayati berpengaruh terhadap berat tongkol dengan kelobot, panjang tongkol dengan kelobot dan tanpa serta diameter tongkol dengan kelobot dan tanpa kelobot, tidak terdapat interaksi terbaik antara varietas dan pupuk hayati, didapatkan varietas terbaik terhadap tinggi tanaman, jumlah daun, diameter batang, berat tongkol dengan kelobot dan tanpa kelobot, panjang tongkol dengan kelobot dan tanpa kelobot serta diameter tongkol dengan kelobot dan tanpa kelobot pada perlakuan $\mathrm{v}_{1}$ (Varietas Bonanza $\mathrm{F}_{1}$ ), didapatkan dosis pupuk hayati terbaik terhadap berat tongkol dengan kelobot dan tanpa kelobot, panjang tongkol dengan kelobot dan tanpa kelobot serta diameter tongkol dengan kelobot dan tanpa kelobot pada perlakuan $\mathrm{h}_{2}\left(100 \mathrm{~kg} \cdot \mathrm{ha}^{-}\right.$ $\left.{ }^{1}\right)$.

\section{DAFTAR PUSTAKA}

Abidin, M., Sugeng Darwanto dan Andayani, R, D. 2017. Pengaruh dosis pupuk organik petroganik dan mikoriza terhadap pertumbuhan dan produksi tanaman jagung manis (Zea mays sccharata) Varietas Talenta. J. Hijau Cendekia. Vol. 2 No. 2.

Antralina, M., Dewi Kania dan Joko Santosa. 2015. Pengaruh pupuk hayati terhadap kelimpahan bakteri penambat nitrogen dan pertumbuhan tanaman kina (Cinvhona ledgeneria Moens) klob cib.5.
Jurnal Penelitian Teh dan Kina Vol. 2 No. 18.

BPS HSU. 2015. Hulu Sungai Utara Dalam Angka 2015. Badan Pusat Statistik. Amuntai.

Dewi, P dan Jumini. 2012. Pertumbuhan dan hasil dua varietas tomat akibat perlakuan jenis pupuk. J. Floratek Vol. 7 No. 76.

Erawati, B. T., R dan Awaludin Hipi. 2009. Daya adaptasi beberapa varietas unggulbaru jagung hibrida di lahan sawah Nusa Tenggara Barat. Prosiding Seminar Nasional Serealia 2009.

Hawayanti, E., Nurbaiti Amir dan Mike Exselen. 2015. Pemberian jenis pupukhayatidan pengaruhnya terhadap pertumbuhan dan produksi tanaman jagunng manis (Zea mays saccharata Sturt) di tanah lebak. Jurnal Klorofil Vol. 10 No. 1.

Husen, E. 2013. Telaah efektivitas pupuk hayati komersial dalam meningkatkan pertumbuhan tanaman. Balai Penelitian Tanah. Bogor.

Laiya, R., Bahua, I dan Nurmi. 2013. Pertumbuhan dan produksi jagung hibrida melalui pemberian pupuk hayati. Jurnal Penelitian Jagung Hibrida Vol. 1 No. 1.

Mahdiannoor. 2014. Pertumbuhan dan hasil tanaman jagung manis (Zea mays L. Var. Saccharata) dengan pemberian pupuk hayati pada lahan rawa lebak. Ziraa'ah Vol. 39 No. 3.

Mahdiannoor dan Nurul Istiqomah. 2015. Pertumbuhan dan hasil dua varietas jagung hibrida sebagai tanaman sela dibawah tegakan karet. Ziraa'ah Vol. 40 No. 1. 
Ningsih, N, D., Neni Marlina dan Erni Hawayanti. 2015. Pengaruh jenis pupuk organik terhadap pertumbuhan dan produksi beberapa varietas jagung manis (Zea mays saccharata Sturt). J. Klorofil No. 10 Vol. 2.

Noor, M. 2007. Rawa Lebak: Ekologi, Pemanfaatan dan Pengembangannya. PT. Raja Grafindo Persada. Jakarta.

Nur Hayati. 2006. Pertumbuhan dan hasil jagung manis pada berbagai waktu aplikasi bokashi limbah kulit buah kakao dan pupuk anorganik. Jurnal Agroland Vol. 13 No. 3.

Patola, E dan Sri Hardiatmi. 2011. Uji potensi tiga varietas jagung dan saat emaskulasi terhadap produktivitas jagung semi (Baby Corn). J. Inovasi Pertanian Vol. 10 No. 1.

Purwanto, S. 2006. Kebijakan Pengembangan Lahan Rawa Lebak. Prosiding Seminar Nasional Lahan Rawa lebak Tahun 2006.

Subagyo, H. 2006. Lahan Rawa Lebak dalam Buku Karakteristik dan Pengelolaan Lahan Rawa. Balai Penelitian dan Pengembangan Pertanian. Bogor.

Suwahyono, U. 2011. Petunjuk Praktis Penggunaan Pupuk Organik secara Efektif dan Efisien. Penebar Swadaya. Jakarta.

Zainuddin, A. 2005. Respon tiga varietas jagung manis (Zea mays saccharata Sturt) terhadap perlakuan pupuk organik. J. Gamma 1 (1). 